Latina/o Students in K-12 Schools: A Synthesis of Empirical Research on Factors Influencing

Academic Achievement

Amanda Taggart

Utah State University 


\begin{abstract}
The purpose of this systematic review is to provide a comprehensive synthesis and analysis of the empirical evidence to date on the factors related to Latina/o student academic achievement in the country's increasingly Latina/o K-12 schools. Factors found to be related to academic achievement outcomes (e.g., grades, test scores, high school completion, college enrollment) for Latina/o students include a combination of (1) demographic variables, (2) sociocultural variables, (3) academic experiences, (4) psychological variables, and (5) school/institutional variables. In addition, this research synthesis identified several methodological trends in the research on Latina/o student success.
\end{abstract}

Keywords: Latina/o students, K-12, academic achievement, literature review 


\section{Latina/o Students in K-12 Schools: A Synthesis of Empirical Research on Factors Influencing Academic Achievement}

Of the over 55 million Latinas/os living in the United States (Stepler \& Brown, 2016), one third are younger than 18 years old, making them the youngest major racial/ethnic group in the nation (Patten, 2016). Latina/o students comprise the largest minority group in elementary and secondary schools in 23 states, including over half of all students in California, Texas, and New Mexico and around 40\% of students in Arizona and Nevada (National Center for Education Statistics, 2015). In addition, Latina/o student enrollment in public K-12 schools is projected to increase $32 \%$ by the year 2023 (Hussar \& Bailey, 2016). However, Latina/o students have the highest rates of school dropout (Davis \& Bauman, 2011) and the lowest rates of high school graduation (Snyder, de Brey, \& Dillow, 2016), enrollment in 4-year colleges and universities (Ortiz, Valerio, \& Lopez, 2012), and bachelor's degree completion (Ryan \& Bauman, 2016) among their White, Black, and Asian peers.

In response to the Latina/o educational crisis (Gándara \& Contreras, 2009; Ocasio, 2014), an increasing body of research has focused on determining which factors are associated with the academic achievement of Latina/o students. Within this work are literature reviews and essays centered on Latina/o students, such as the state of research regarding Latina/o students' experiences in K-16 education (R. Padilla, 2007), Latina/o academic attainment (Ayala, 2012), Latina/o parents' involvement with mathematics education (C. O. Lopez \& Donovan, 2009), and how college outreach programs impact Latina/o high school students (Loza, 2003); however, to date, there has been no comprehensive literature review conducted that synthesizes the scholarship specific to Latina/o academic achievement outcomes in K-12 schools. As educators across the country become the instructional leaders of increasingly Latina/o student bodies, it is 
imperative that they understand which factors are most related to Latina/o student academic achievement. In addition, as Pounder and Johnson (2009) state, “. . .the need for and potential contributions of rigorous and comprehensive literature reviews that can inform and anchor future knowledge development within the field has increased" (p. 3). Therefore, the current review seeks to provide a comprehensive synthesis and analysis of the empirical evidence to date on Latina/o academic achievement in elementary and secondary schools.

Although there are many ways to conceptualize academic achievement, this review focuses on the outcomes studied most often in the reviewed scholarship. The most prevalent achievement outcomes examined by researchers were grades, test scores, high school completion, and college enrollment. The decision to review research focusing strictly on traditional academic achievement outcomes is not meant to undervalue research investigating the structural, societal, cultural, and economic conditions influencing Latina/o students' access to equality in the American educational system. For example, research has been conducted on Latina/o students' lack of access to high quality, rigorous curriculum (e.g., Solórzano \& Ornelas, 2004), feelings of marginalization and their effects on Latina/o students' schooling experiences (Meador, 2005; Quiroz, 2001), teachers' attitudes and behavior toward students with whom they perceive themselves to have cultural differences (e.g., Fergus, 2009; Tan, 2001), and the lack of cultural responsiveness to Latina/o students in schools (e.g., Marx, 2008; Tan, 2002). Although these are all important areas of research and it is recognized that they are intertwined with Latina/o academic achievement, such investigations fall outside the scope of the current study. By identifying factors that facilitate or inhibit academic achievement for Latina/o students, this study purposes to offer insight into how to increase educational success for this traditionally underserved group. While a substantial amount of research has been conducted in this area, the 
volume of work, as well as its scattering in journals across academic disciplines, makes it difficult for educators to access all of the relevant information on the subject. This review, therefore, is an attempt to provide a comprehensive synthesis of the scholarship to date in order to encourage dialogue, as well as changes in practice, among educators working with Latina/o students. As such, the following research question guides this study: What factors are related to Latina/o student academic achievement in K-12 schools? The subsequent sections describe the methodology used to steer the review and then discuss the findings from the literature.

\section{Method}

The purpose of a literature review is to critically evaluate published scholarly material in order to consider the progress of research toward clarifying a problem; to inform an audience of the state of research; to identify relationships, contradictions, and gaps in the literature; and to recommend next steps in solving the problem (American Psychological Association, 2010). Consistent with the research question guiding the review, nine electronic databases were searched for applicable research: (1) Academic Search Complete, (2) Education Full Text, (3) Education Research Complete, (4) ERIC (via EBSCO), (5) Chicano Database, (6) Social Sciences Full Text, (7) SocINDEX, (8) PsycARTICLES, and (9) PsycINFO. Combinations of key search terms including "Hispanic," “Latina," "Latino," “students," "academic achievement," “academic outcomes," "academic success," "educational outcomes," and "educational attainment" were used to search these databases. In addition, individual journals thought to contain pertinent research were manually searched, as well as the reference pages of appropriate articles that were already located. Although all scholarship conducted prior to October 2016 was considered for the current study, relevant studies generally fell into the last 15 years. 
After locating all articles thought to be germane to this review, each article was read and a database was created to sort and code the following characteristics for the identified studies: (1) purpose and/or research questions, (2) theory or conceptual models, (3) research design, (4) survey scales (if used), (5) school level, (6) outcome(s), and (7) results. Empirical research that used quantitative or qualitative methods to understand and/or test relationships between one or more variables and academic achievement outcomes among Latina/o students in elementary or secondary schools was selected for inclusion in this study. Studies investigating more than one minority group were included if the results were disaggregated by racial/ethnic group and the findings for Latina/o students were reported separately from other groups. Investigations that did not explicitly address academic achievement outcomes (e.g., aspirations, engagement, sense of belonging), studies that described trends in data, and research that focused on preschool or college student samples were excluded from review.

The complete search produced 170 articles, which were then reduced to 134 studies after the initial analysis of suitability. A critical evaluation of the research found to meet all of the inclusion/exclusion criteria identified several factors found to be related to one or more academic achievement outcomes for Latina/o students. These factors were then organized into five themes: (1) demographic variables, (2) sociocultural variables, (3) academic experiences, (4) psychological variables, and (5) school/institutional variables.

\section{Results}

The most prevalent academic achievement outcomes examined in the 134 studies found to meet all of the inclusion and exclusion criteria were grades or grade point average (GPA), test scores (with mathematics test scores being studied more often than English Language Arts test scores), high school completion, and college enrollment, while less attention was given to 
attendance, disciplinary issues, school readiness, literacy, and general "academic success." Although $37 \%$ of the reviewed research was located in education journals, the majority of studies were found in publications outside the field of education (63\%). These studies were found mainly in psychology (40\%) and sociology (9\%) journals, with the remaining $15 \%$ coming from journals representing a variety of fields (i.e., social work, social science, demography, ethnic studies, culture, economics, child welfare, political science, and multidisciplinary studies). The first studies appeared in the early 1990s (Reyes, 1993; Reyes \& Jason, 1991), though the research on Latina/o academic achievement outcomes did not become more prevalent until the early 2000s. From 2009 to 2015, published studies have been in the low double digits (between 10 and 18 articles per year) each consecutive year except for one (2010).

The large majority of reviewed studies utilized quantitative methods $(86 \%)$, while only seven studies (5\%) used exclusively qualitative methods and approximately $9 \%$ used mixed methodologies. The quantitative studies used almost wholly non-experimental designs and relied predominantly on survey methods. Roughly one third of these studies were produced from the analyses of at least one of four national longitudinal data sets: (1) the National Education Longitudinal Study (NELS), (2) the Educational Longitudinal Study (ELS), (3) the Early Childhood Longitudinal Study-Kindergarten (ECLS-K), and (4) the National Longitudinal Study of Adolescent Health (Add Health). The most prominent methods of statistical analyses used in the quantitative studies were various regression models, hierarchical linear modeling (HLM), structural equation modeling (SEM), and descriptive statistics. Interviews and focus groups made up the dominant data collection in the qualitative studies, two of which were conducted using an ethnographic approach while phenomenological and grounded theory approaches were used in 
one study each. The remainder of the qualitative studies failed to specify a research paradigm. All of the qualitative studies were conducted with high school samples.

Of the analyzed studies, $62 \%$ were conducted using samples of exclusively secondary students, with the majority of those set at the high school level (50\% compared with approximately $12 \%$ at the junior high or middle school level). Twenty-two of the studies (17\%) focused on elementary school students, while 24 studies $(18 \%)$ used samples from across elementary and secondary grades and four studies (3\%) did not specify a grade level. Although some of the published articles outlined a theoretical or conceptual framework to guide the study (e.g., Bandura's academic self-efficacy theory; Bronfenbrenner's ecological culture theory; Moll's Funds of Knowledge; Hossler and Stage's college choice theory; Ogbu's oppositional culture theory), the majority did not, and no theory was cited in more than one of the reviewed studies.

\section{Factors Associated With Latina/o Academic Achievement}

The literature on the factors associated with Latina/o academic achievement includes studies focusing on five areas: (1) demographic variables, (2) sociocultural variables, (3) academic experiences, (4) psychological variables, and (5) school/institutional variables. Each of these areas will be discussed in the following sections.

Demographic variables. Empirical findings indicate that several demographic variables influence Latina/o academic achievement, including gender, ethnicity, generational status, native language, and socioeconomic status (SES). In regard to the relationship between gender and academic achievement, with few exceptions related to mathematics test scores (e.g., Hong \& You, 2012; Mosqueda \& Maldonado, 2013), being female is overwhelmingly associated with the academic success outcomes of school readiness (Furlong \& Quirk, 2011), grades (e.g., Cupito, 
Stein, \& Gonzalez, 2015), test scores (Lapayese, Huchting, \& Grimalt, 2014), high school completion (Zarate \& Pineda, 2014), and college enrollment (Weiher, Hughes, Kaplan, \& Howard, 2006; Zarate \& Gallimore, 2005).

The Latina/o ethnicities researched most often in the literature concentrated on students of Mexican, Puerto Rican, and Cuban backgrounds, though students from other Latin American backgrounds were also included in studies on occasion (e.g., Tillman, Cuo, \& Harris, 2006). Being of Mexican origin proved to be a risk factor for students in most research studies, with those students receiving lower grades and test scores and having lower rates of high school completion and college enrollment than students of other nationalities (e.g., Claster \& Blair, 2013; Crosnoe, 2005).

Research investigating the relationship between generational status and the achievement of Latina/o students has shown mixed findings. With the exception of one study (Alfaro, UmañaTaylor, Gonzales-Backen, Bámaca, \& Zeiders, 2009), Latina/o immigrant students' grades have been shown to be higher than those of U.S.-born Latina/o students (Crosnoe, 2005; A. M. Padilla \& Gonzalez, 2001). However, other studies have found that teachers rate the academic performance of U.S.-born Latina/o students higher than their peers born outside the United States (e.g., Fite, Rubens, \& Cooley, 2014; Supple, Chazatian, Frabutt, Plunkett, \& Sands, 2006). High school completion (e.g., Claster \& Blair, 2013; Zarate \& Pineda, 2014) and college enrollment (Riegle-Crumb, 2010; Zarate \& Gallimore, 2005) have also been shown to be lower for immigrant students. For instance, using hierarchical generalized linear models in a study of over 26,000 Latina/o students in a large urban school district, Zarate and Pineda (2014) found that for U.S.-born Latinas/os, the odds of high school completion were $22 \%$ greater than that of immigrant Latina/o students. 
Similar to the research on generational status, studies examining native language also show mixed results. For example, in two nationally representative longitudinal studies, being proficient in Spanish and/or speaking Spanish at home has been shown to be negatively related to mathematics test scores at the elementary level (Hong \& You, 2012), though it has been positively associated with English Language Arts (ELA) test scores at the secondary level (Guglielmi, 2008). These differences may be related to the subject matter of the tests or the school level of the students taking the tests. Moreover, speaking Spanish at home during elementary school has been shown to positively affect high school completion (Zarate \& Pineda, 2014) and being bilingual in both Spanish and English is also positively related to achievement (Supple et al., 2006). However, speaking English in the home has been shown to increase college enrollment (e.g., Weiher et al., 2006), including the odds of enrolling in a 4-year college rather than in a 2-year postsecondary school (Taggart \& Crisp, 2011).

Researchers generally concur that SES impacts the majority of achievement outcomes, including test scores (e.g., Bécares \& Priest, 2015), grades (e.g., Azmitia, Cooper, \& Brown, 2009), high school completion (Claster \& Blair, 2013; Zarate \& Pineda, 2014), college enrollment (Song \& Elliott, 2012), and student discipline (e.g., H. Park, Lin, Liu, \& Tabb, 2015). SES is measured in various ways in the literature, including family income, qualifying for Free and Reduced Lunch (FRL), parental home ownership, receiving in-kind welfare benefits, and college savings. All but one of the reviewed studies (F. López, 2011) on the association between SES and test scores were conducted with large, nationally representative data sets (e.g., ECLS-K, ELS: 2002; NELS:88) and concluded that higher SES correlated to higher test scores in core subjects (e.g., Bécares \& Priest, 2015; Hong \& You, 2012; Lleras \& Rangel, 2009; Mosqueda \& Maldonado, 2013). Across studies, published research also indicated that higher SES is 
associated with higher grades (Azmitia et al., 2009; Claster \& Blair, 2013; Crosnoe, 2005; Maynard, Kjellstrand, \& Thompson, 2014).

In addition, age was related to Latina/o student success only at the elementary school level, where younger students had better grades (H. Park et al., 2015) but lower test scores (Furlong \& Quirk, 2011; Quirk, Nylund-Gibson, \& Furlong, 2013), while older students had more discipline problems (H. Park et al., 2015).

Sociocultural variables. Research findings to date have shown that academic success among Latina/o students is related to home and family support, student peer groups, parental education levels, extracurricular participation, English proficiency, neighborhood variables, and cultural variables. Home and family support is the sociocultural variable which has been included most often in research on Latina/o student academic achievement and provides strong evidence that the support of Latina/o parents is crucial to the academic achievement of their children, as parental involvement, interest, encouragement, and monitoring are all positively related to student test scores (e.g., Chun \& Dickson, 2011; Mena, 2011). In several quantitative studies examining hundreds of students in various schools and districts in the western United States, higher levels of parental support in the forms of academic encouragement, parental monitoring, and supportive parent relationships were associated with higher grades (e.g., LeCroy \& Krysik, 2008; Santiago, Gudiño, Baweja, \& Nadeem, 2014). Moreover, high parent expectations for their children's success are associated with students' test scores and college enrollment (e.g., Kalogrides, 2009). For instance, in longitudinal studies, Latina/o parents' college expectations for their children were found to be predictive of their 4-year college enrollment (Song \& Elliott, 2012; Zarate \& Gallimore, 2005). The support of siblings is also related to student grades (Azmitia et al., 2009) and siblings' college experience is associated with 
Latina/o college enrollment (Weiher et al., 2006). In addition, parent-school involvement is positively related to grades and high school completion (e.g., Jabagchourian, Sorkhabi, Quach, \& Strage, 2014).

Similar to the support students receive from their families, support from their peer groups also has been shown to influence Latina/o academic achievement. While having a pro-academic peer group is associated with better grades (e.g., LeCroy \& Krysik, 2008), higher rates of high school completion (Lagerwey, Phillips, \& Fuller, 2003) and college enrollment (e.g., RiegleCrumb, 2010), and lower incidences of disciplinary action against students (Oyserman, Brickman, Bybee, \& Celious, 2006), findings on the effects of socializing in racially and ethnically homo- or heterogeneous peer groups are not as clear. For example, though socializing with other Latina/o students has been shown to negatively correspond with test scores (e.g., Kalogrides, 2009), research examining grades and high school completion show mixed results. Concerning grades, Goza and Ryabov (2009) found that when Latina/o student networks were more homogeneous, students were more likely to have higher grades and to graduate from high school. However, Guzmán, Santiago-Rivera, and Haase (2005) found that whether Latina/o students were inclined to socialize with other ethnic groups was associated with higher grades. These differences in findings may be due to sample size or geography, as the former study utilized a nationally representative longitudinal data set of nearly 14,000 Latina/o students while the latter analyzed just over 200 students in one state.

Parental education levels, including immigrant parents' pre-migration education (Pong \& Landale, 2012), have also been found to influence test scores (e.g., Hannon, 2015), grades (e.g., Rios-Aguilar, 2010), college enrollment (Taggart \& Crisp, 2011; Riegle-Crumb, 2010; Song \& Elliott, 2012), and discipline issues (Prelow \& Loukas, 2003) among Latina/o students. The 
educational level of mothers is also specifically cited in the literature as contributing to Latina/o student academic outcomes (Claster \& Blair, 2013; Prelow \& Loukas, 2003).

Overarchingly, the literature has identified participation in extracurricular activities as having a positive effect on Latina/o student success in the form of test scores (J. A. Espinoza, Lunenburg, \& Slate, 2013; Prelow \& Loukas, 2003), grades (e.g., Crosnoe, 2005), high school completion (Flores-González, 2000; Lagerwey et al., 2003), college enrollment (e.g., Taggart \& Crisp, 2011), attendance (Flores-González, 2000), and discipline (Flores-González, 2000; Prelow \& Loukas, 2003).

Adding to the variables that have been found to have positive effects on Latina/o student achievement, English proficiency is related to student test scores (Barrett et al., 2012; Mosqueda \& Maldonado, 2013), grades (Alfaro et al., 2009; Claster \& Blair, 2013; Santiago et al., 2014), high school completion (Zarate \& Pineda, 2014), and college enrollment (Zarate \& Gallimore, 2005), while biliteracy achievement in Spanish and English was positively related to high school completion, college enrollment, and enrollment in bachelor's degree programs (Lutz, 2004). Where Latina/o students live also affects their academic success outcomes. For example, the percentage of a city's Latina/o population (Mayer, 2004) and living in the western United States (Riegle-Crumb \& Callahan, 2009) have both been associated with high school completion, though living in a disadvantaged neighborhood is negatively related to test scores and student discipline issues (Prelow \& Loukas, 2003). Moreover, Fite et al.'s (2014) analysis of high school students in a large Midwestern city revealed that when levels of neighborhood violence were high, Latina/o students' academic performance was low.

Cultural variables have also been shown to be associated with Latina/o student achievement. For instance, Latina/o students who exhibit more mainstream cultural values have 
been shown to have lower test scores (Santiago et al., 2014), though the generally accepted Latina/o cultural value of familism has been positively related to grades (Cupito et al., 2015) and school attendance (Esparza \& Sánchez, 2008). In addition, cultural discontinuity between mainstream and Latina/o cultural values at home and at school has been found to be negatively associated with grades (Taggart, 2017).

Academic experiences. Numerous studies have examined the influence of academic experiences on Latina/o educational achievement. This body of research includes taking more rigorous courses, prior academic achievement, participating in school and/or community programs designed to improve student success, positive interactions with school faculty and staff, students' personal study behaviors, and student attendance as variables related to Latina/o academic achievement.

Scholarly literature regarding rigorous course-taking shows positive relationships between taking more and higher level mathematics courses (e.g., Taggart \& Crisp, 2011; Mosqueda \& Maldonado, 2013) as well as Advanced Placement (AP) and/or International Baccalaureate (IB) courses (e.g., Riegle-Crumb, 2010) as contributing to student test scores and college enrollment. Two studies using data from the ELS show this relationship well. Mosqueda and Maldonado (2013) used HLM to show that every additional higher level mathematics course taken by Latina/o high school students was associated with a three-point positive difference in 12th-grade mathematics IRT (item response theory)-scaled scores. In addition, Taggart and Crisp (2011) found that taking an additional mathematics course in high school increased the odds of enrolling in a 4-year college by a factor of 1.76 and that the odds of enrolling in a 4-year school were almost 5 times as large for those students who were enrolled in AP courses during high school. 
In addition to course-taking rigor, students' achievement or ability in previous grades has been shown to positively impact test scores (e.g., Furlong \& Quirk, 2011; Lleras \& Rangel, 2009; E. M. Lopez, Gallimore, Garnier, \& Reese, 2007; Valle, Diaz, Waxman, \& Padrón, 2013), grades (Rios-Aguilar, 2010), high school completion (Claster \& Blair, 2013; Lutz, 2004; Zarate \& Pineda, 2014), and college enrollment (Griffin, 2002; Riegle-Crumb, 2010; Song \& Elliott, 2012; Weiher et al., 2006; Zarate \& Gallimore, 2005). For instance, Song and Elliott (2012) utilized hierarchical linear growth modeling with the ELS:2002 data set to show that for every one-unit increase in GPA, the odds of Latina/o students' college enrollment increased by 2.25 times. Similarly, Griffin (2002) studied students at 75 high schools in Florida and found that a one-unit increase in GPA increased Latina/o students' odds of staying in school by $136 \%$. Moreover, prior schooling in Mexico and English as a Second Language (ESL) or bilingual instruction have been found to improve student grades (A. M. Padilla \& Gonzalez, 2001). Furthermore, previous academic failures have been negatively associated with high school completion (Reyes, 1993; Zarate \& Pineda, 2014).

Overall research findings to date indicate that participating in school and/or community programs designed to improve student success is related to improvement in school readiness (Yoshikawa, Gassman-Pines, Morris, Gennetian, \& Godfrey, 2010), test scores (e.g., Borrero, 2011), grades (Maynard et al., 2014), high school completion (e.g., Gibson \& Bejínez, 2002), and college enrollment (Weiher et al., 2006). Examples of such programs specifically cited in the literature include AVID and GEAR UP (e.g., Lozano, Watt, \& Huerta, 2009), ESL (Claster \& Blair, 2013) and bilingual education programs (e.g., Lindholm-Leary \& Borsato, 2005), and other school-specific intervention programs that have been implemented by faculty at individual school sites (e.g., Johnson \& Fargo, 2014; Reyes \& Jason, 1991). School-specific interventions 
included programs such as interpreting programs (Borrero, 2011) and teacher-led guidance and counseling classes (Reyes \& Jason, 1991).

Apart from designated programs, Latina/o students' positive experiences with school faculty and staff have been shown to influence their achievement. Among these experiences are having caring teachers (e.g., Garrett, Antrop-González, \& Vélez, 2010; Riconscente, 2014); receiving courage, guidance, and support from adults at school (e.g., Azmitia et al., 2009; Lagerwey et al., 2003; Rivas-Drake, 2011); interacting with school counselors regarding college (Weiher et al., 2006); and experiencing various types of specific teaching practices (e.g., F. López, 2011; Turner \& Celedón-Pattichis, 2011; Valle et al., 2013) such as high-ability grouping (Lleras \& Rangel, 2009), content explanations (Riconscente, 2014), and culturally responsive teaching (Chun \& Dickson, 2011). Such interactions between Latina/o students and school faculty and staff have been associated with students' test scores, grades, high school completion, college enrollment, and discipline.

Next, students' study behaviors have been shown to impact their achievement (e.g., H. S. Park \& Yau, 2014). In particular, the hours spent working on and completing homework has been positively related to grades, high school completion, and college enrollment (e.g., RiegleCrumb, 2010). Current research also reveals that school attendance is a necessary component of Latina/o academic success. For instance, high attendance is positively related to high school completion (Reyes, 1993) and college enrollment (Weiher et al., 2006). However, transience has been shown to be negatively related to high school completion and test scores (e.g., Reyes, 1993).

Psychological variables. Prior research that has examined psychological variables which contribute to Latina/o academic achievement include studies on perceived discrimination and/or 
racism, racial/ethnic identity, academic motivation and engagement, feelings of school satisfaction or belonging, and other psychological and emotional factors. First, discriminatory experiences have been show to negatively influence Latina/o student achievement in regard to grades and college enrollment (e.g., Alfaro et al., 2009; Taggart \& Crisp, 2011). In addition, experiencing stereotype threat, the idea that students' ability to perform academically is diminished by their anxiety over negative stereotypes of their own social group (e.g., being Latina/o; Steele, 2010; Steele \& Aronson, 1995; Walton \& Spencer, 2009), is negatively related to test scores (Rodríguez, 2014). However, feeling higher public regard for students' ethnicity is positively related to grades (Rivas-Drake, 2011).

Second, research on the influence of racial/ethnic identity on achievement (e.g., Garrett et al., 2010; Supple et al., 2006) has shown that having a strong ethnic identity is positively related to grades (e.g., Chang \& Le, 2010) while having a bicultural identity is positively associated with test scores (Zarate, Bhimji, \& Reese, 2005). For instance, among students of Mexican descent, Zarate et al. (2005) conducted a longitudinal study of 79 Spanish-speaking families in Los Angeles and found that students who identified with the labels of Mexican American, American, or Chicano significantly outperformed all other groups on reading and mathematics test scores.

Furthermore, there is agreement within the literature that high academic motivation as well as both academic and behavioral engagement in class are positively related to test scores and grades (e.g., Boutakidis, Rodríguez, Miller, \& Barnett, 2014). Moreover, cognitive selfcompetence is positively correlated with grades (Alva \& de Los Reyes, 1999) and self-efficacy is positively related to test scores, grades, and attendance (e.g., Chun \& Dickson, 2011; Riconscente, 2014). As expected, having higher college aspirations and expectations are positively correlated with college enrollment (e.g., Taggart \& Crisp, 2011; Song \& Elliott, 2012). 
In addition to research on discrimination, ethnic identity, and motivation, studies have detailed the positive effects of feelings of school belonging, school satisfaction, and school acculturation on Latina/o student achievement (e.g., Fite et al., 2014), including their grades (Maurizi, Ceballo, Epstein-Ngo, \& Cortina, 2013), attendance (Sánchez, Colón, \& Esparza, 2005), and high school completion (e.g., Reyes, 1993). Other psychological and emotional factors that contribute negatively to Latina/o student achievement, however, include externalizing symptoms such as adolescent conduct disorder (CD) and opposition defiant disorder (ODD; Roosa et al., 2012), psychosocial (Alva \& de Los Reyes, 1999) and acculturative stress (Santiago et al., 2014), depression (Basáñez, Warren, Crano, \& Unger, 2014), and fatalism (Basáñez et al., 2014; Guzmán et al., 2005), or "the extent to which people feel their destinies are out of their control" (Guzmán et al., 2005, p. 6), while self-esteem has been shown to positively affect Latina/o student grades (Jiang, Yau, Bonner, \& Chiang, 2011). In addition, loneliness has been negatively related to test scores (Benner, 2011), feeling bullied has been found to negatively correspond with attendance (G. Espinoza, 2015), and socioemotional competence has been negatively related to student discipline issues (Prelow \& Loukas, 2003).

School/institutional variables. Finally, several school/institutional variables have been found to be related to Latina/o student achievement. Among the most-researched of these factors are the racial composition of the student body, racial segregation and stratification within school courses, and school SES. By and large, research has shown that attending schools with predominantly Latina/o or minority populations has negative consequences for Latina/o students' grades (Crosnoe, 2005; Ryabov \& Van Hook, 2007), test scores (e.g., Lleras \& Rangel, 2009), and high school completion (Riegle-Crumb \& Callahan, 2009; Zarate \& Pineda, 2014). In addition, when Latina/o students attend schools where academic courses are racially segregated 
or stratified, students have been found to be negatively affected in terms of their grades (Muller, Riegle-Crumb, Schiller, Wilkinson, \& Frank, 2010) and test scores (e.g., Berends \& Peñaloza, 2010).

The body of research examining the socioeconomic composition of schools and Latina/o academic achievement universally indicates that higher school SES is associated with higher achievement in relation to nearly all forms of achievement (e.g., Goza \& Ryabov, 2009; Kalogrides, 2009; Mosqueda \& Maldonado, 2013; Ryabov \& Van Hook, 2007; Song \& Elliott, 2012). For instance, Ryabov and Van Hook (2007) analyzed data from the National Longitudinal Study of Adolescent Health (Add Health) and found that school SES was a strong predictor of both GPA and test scores among Latina/o students, and Kalogrides (2009) used ELS:2002 to show that students attending schools with fewer poor students had higher reading and mathematics test scores.

\section{Discussion}

This synthesis of empirical research enhances prior work examining the factors related to Latina/o academic achievement in K-12 schools by assembling the results of this body of literature in one place in order to assist researchers and educators to locate the information they need to facilitate academic success for Latina/o students in schools. The current review also identified several methodological trends in the research on Latina/o academic achievement. For example, the majority of the work reviewed for this study relied on quantitative methods and the use of national longitudinal data sets in secondary schools (mainly high schools). While such work is no doubt important, it underscores the lack of qualitative work in the area, as well as work conducted in elementary schools. For instance, results of this synthesis suggest that students' prior academic achievement plays an important role in their later academic success; 
however, only a small percentage $(17 \%)$ of the reviewed research has taken place in elementary schools. There remain, therefore, substantial gaps in our knowledge regarding what is being done in elementary schools to improve students' academic achievement in secondary schools, which would in turn increase their access to postsecondary education. Furthermore, considering the findings of multiple studies showing that home and family support is crucial to the academic achievement of Latina/o students, it is imperative that more qualitative work is conducted in order to understand how schools involve parents and other caregivers in their children's academic successes. Although the scholarship to date has identified a number of school and community programs that influence students' academic achievement, it remains unclear how these programs are involving families in their work. Qualitative work centered on this topic would contribute greatly to our understanding of family inputs that influence student achievement.

Moreover, this review found that approximately one third of all studies on K-12 Latina/o student achievement analyzed data from one of four national data sets. While research that employs national data sets may be largely generalizable to Latina/o students across the United States, some limitations must be considered when examining the usefulness of their results. For example, data collection for these studies may not precisely reflect the experiences of Latina/o students, as they were developed for all students rather than just Latinas/os. This may require scholars "to rely on ethnocentric definitions of variables" (Crisp, Taggart, \& Nora, 2015, p. 262) rather than on variables that may be more applicable across race/ethnicity.

The analysis of the research reviewed in this study revealed several other noteworthy findings. For example, results suggest that Latina/o students' academic achievement is directly influenced by their experiences in school, including inter- and intra-school segregation, 
experiences with school faculty and staff, and prior academic achievement. Given the findings from this review that reveal attending schools with predominantly Latina/o populations has negative consequences for Latina/o students' academic achievement, it is necessary to expand the work of scholars who have described such schools as lacking the resources enjoyed by predominantly White schools, including a lack of adequate facilities (Jimenez-Castellanos, 2010) and noncertified or emergency-credentialed teachers (Jimenez-Castellanos, 2010; Valencia, 2000) who do not belong to the same racial/ethnic groups of their students (Duncan-Andrade, 2005), to what impact such lack of resources may have on actual achievement outcomes. Apart from interschool segregation, results of this review show that intraschool segregation, in particular the tracking of Latina/o students into low-level courses, contributes to their low achievement outcomes. Future research, then, should investigate how schools with high rates of Latina/o students in upper level courses are promoting rigorous course-taking for these students.

In addition, present results reveal that Latina/o students' experiences with school faculty and staff contribute to their academic achievement through culturally specific teaching practices and positive relationships. Although the promotion of culturally relevant pedagogy has been endorsed by many scholars as a tactic to combat existing inequities and discriminatory practices in the schooling process for diverse groups of students (e.g., Ladson-Billings, 2009), the bulk of the literature on culturally congruent instructional practices has been limited to descriptions of culturally relevant environments and methods (e.g., Enyedy \& Mukhopadhyay, 2007; Hall \& Damico, 2007; Leonard, Napp, \& Adeleke, 2009; Moses \& Cobb, 2001; Wortham \& Contreras, 2002), problems associated with the implementation of culturally relevant pedagogy (e.g., DeJaeghere \& Zhang, 2008; Jennings \& Smith, 2002), characteristics of culturally responsible teachers (e.g., Garza, 2009; Hermes, 2005; Hughes, 2003; Lewis \& Kim, 2008; Van Horn, 
2000), and the effects of culturally relevant pedagogy on student engagement (Gutstein, 2003; Noguera, 2001), but has rarely focused on the impact of components of culturally relevant pedagogy on student academic achievement outcomes, and those that do consist mainly of smallscale case studies (Sleeter, 2010). Furthermore, research that has examined culturally relevant pedagogy has focused largely on elementary school-age African American students (e.g., Boykin \& Bailey, 2000; Boykin \& Cunningham, 2001; Boykin, Lilja, \& Tyler, 2004; Komarraju \& Cokely, 2008) but has largely ignored the effects of culturally relevant pedagogy for Latina/o students. In addition, with few exceptions (e.g., Sheets, 1995), published studies generally have not directly investigated the relationship between culturally relevant pedagogy and the academic achievement of racial/ethnic minority youth (Sleeter, 2010). Because of the myriad difficulties faced by Latinas/os in the American educational system, research examining the effects of culturally relevant pedagogy on Latina/o academic achievement is necessary to improve the educational outcomes for this large and ever-growing group of K-12 students.

Finally, findings of the present review highlight the need for educators to help build social capital among Latina/o students, especially for first-generation college-going students regarding access to postsecondary education. However, it is unclear how school faculty provide their students with information and experiences that lead to their high school completion and college enrollment, including guidance on course-taking pathways in high school, college admissions information, and resources regarding financial aid for students who want to attend college, which would also help to counteract the low college enrollment rates for students from low-SES backgrounds attending low-SES schools, as emphasized in the research synthesis. 


\section{References}

References marked with an asterisk indicate studies included in the literature review.

*Alfaro, E. C., Umaña-Taylor, A. J., Gonzales-Backen, M. A., Bámaca, M. Y., \& Zeiders, K. H. (2009). Latino adolescents' academic success: The role of discrimination, academic motivation, and gender. Journal of Adolescence, 32, 941-962.

doi:10.1016/j.adolescence.2008.08.007

*Alva, S. A., \& de Los Reyes, R. (1999). Psychosocial stress, internalized symptoms, and the academic achievement of Hispanic adolescents. Journal of Adolescent Research, 14, 343358.

American Psychological Association. (2010). Publication manual of the American Psychological Association (6th ed.). Washington, DC: Author.

Ayala, M. I. (2012). The state of research in Latino academic attainment. Sociological Forum, 27, 1037-1045. doi:10.1111/j.1573-7861.2012.01367.x

*Azmitia, M., Cooper, C. R., \& Brown, J. R. (2009). Support and guidance from families, friends, and teachers in Latino early adolescents' math pathways. Journal of Early Adolescence, 29, 142-169. doi:10.1177/0272431608324476

*Barrett, A. N., Barile, J. P., Malm, E. K, \& Weaver, S. R. (2012). English proficiency and peer interethnic relations as predictors of math achievement among Latino and Asian immigrant students. Journal of Adolescence, 35, 1619-1628. doi: 10.1016/j.adolescence.2012.08.002

*Basáñez, T., Warren, M. T., Crano, W. D., \& Unger, J. B. (2014). Perceptions of intragroup rejection and coping strategies: Malleable factors affecting Hispanic adolescents' 
emotional and academic outcomes. Journal of Youth and Adolescence, 43, 1266-1280. doi:10.1007/s10964-013-0062-y

*Bécares, L., \& Priest, N. (2015). Understanding the influence of race/ethnicity, gender, and class on inequalities in academic and non-academic outcomes among eighth-grade students: Findings from an intersectionality approach. PLoS ONE, 10, e0141363. doi:10.1371/journal.pone.0141363

*Benner, A. D. (2011). Latino adolescents' loneliness, academic performance, and the buffering nature of friendships. Journal of Youth and Adolescence, 40, 556-567. doi:10.1007/s10964-010-9561-2

*Berends, M., \& Peñaloza, R. (2010). Increasing racial isolation and test score gaps in mathematics: A 30-year perspective. Teachers College Record, 112, 978-1007.

*Borrero, N. (2011). Nurturing students' strengths: The impact of a school-based student interpreter program on Latino/a students' reading comprehension and English language development. Urban Education, 46, 663-688. doi:10.1177/0042085911400333

*Boutakidis, I. P., Rodríguez, J. L., Miller, K. K., \& Barnett, M. (2014). Academic engagement and achievement among Latina/o and non-Latina/o adolescents. Journal of Latinos and Education, 13, 4-13. doi: 10.1080/15348431.2013.800815

Boykin, A. W., \& Bailey, C. T. (2000). The role of cultural factors in school relevant cognitive functioning: Synthesis of findings in cultural contexts, cultural orientations, and individual differences. Report No. 42. Published by the Center for Research on the Education of Students Placed at Risk (CRESPAR), supported as a national research and development center by the Office of Educational Research and Improvement (OERI), U.S. Department of Education (R-117-D40005). 
Boykin, A. W., \& Cunningham, R. T. (2001). The effects of movement expressiveness in story content and learning context on the analogical reasoning performance of AfricanAmerican children. The Journal of Negro Education, 70, 72-83.

Boykin, A. W., Lilja, A. J., \& Tyler, K. M. (2004). The influence of communal vs. individual learning context on the academic performance in social studies of Grade 4-5 AfricanAmericans. Learning Environments Research, 7, 227-244.

*Chang, J., \& Le, T. N. (2010). Multiculturalism as a dimension of school climate: The impact on the academic achievement of Asian American and Hispanic youth. Cultural Diversity and Ethnic Minority Psychology, 16, 485-492.

*Chun, H., \& Dickson, G. (2011). A psychoecological model of academic performance among Hispanic adolescents. Journal of Youth and Adolescence, 40, 1581-1594. doi:10.1007/s10964-011-9640-z

*Claster, P. N., \& Blair, S. L. (2013). Latino and Latina educational attainment: An investigation of bi-lingual language abilities and the familial context. Sociological Viewpoints, 29, 5986.

Crisp, G., Taggart, A., \& Nora, A. (2015). Undergraduate Latina/o students: A systematic review of research identifying factors contributing to academic success outcomes. Review of Educational Research, 85, 249-274. doi: 10.3102/0034654314551064

*Crosnoe, R. (2005). The diverse experiences of Hispanic students in the American educational system. Sociological Forum, 20, 561-588. doi:10.1007/s11206-005-9058-z

*Cupito, A. M., Stein, G. L., \& Gonzalez, L. M. (2015). Familial cultural values, depressive symptoms, school belonging and grades in Latino adolescents: Does gender matter? Journal of Child Fam Studies, 24, 1638-1649. doi: 10.1007/s10826-014-9967-7. 
Davis, J., \& Bauman, R. (2011). School enrollment in the United States: 2011 (P20-564). U.S. Census Bureau. Retrieved from https://www.census.gov/ prod/2013pubs/p20-571.pdf

DeJaeghere, J. G., \& Zhang, Y. (2008). Development of intercultural competence among U.S. American teachers: Professional development factors that enhance competence. Intercultural Education, 19, 255-268.

Duncan-Andrade, J. M. R. (2005). An examination of the sociopolitical history of Chicanos and its relationship to school performance. Urban Education, 40, 576-605. doi: $10.1177 / 0042085905281391$

Enyedy, N., \& Mukhopadhyay, S. (2007). They don't show nothing I didn’t know: Emergent tensions between culturally relevant pedagogy and mathematics pedagogy. The Journal of Learning Sciences, 16, 139-174.

*Esparza, P., \& Sánchez, B. (2008). The role of attitudinal familism in academic outcomes: A study of urban, Latino high school seniors. Cultural Diversity and Ethnic Minority Psychology, 14, 193-200. doi:10.1037/1099-9809.14.3.193

*Espinoza, G. (2015). Daily cyber-victimization among Latino adolescents: Links with emotional, physical and school adjustment. Journal of Applied Developmental Psychology, 38, 39-48.

*Espinoza, J. A., Lunenburg, F. C., \& Slate, J. R. (2013). Hispanic middle school students and school sponsored activities: Relationships with achievement and behavior. The Journal of Educational Research, 7, 269-287.

Fergus, E. (2009). Understanding Latino students' schooling experiences: The relevance of skin color among Mexican and Puerto Rican high school students. Teachers College Record, $111,339-375$. 
*Fite, P. J., Rubens, S. L., \& Cooley, J. L. (2014). Influence of contextual factors on academic performance in a sample of Latino adolescents: The moderating role of school attachment. Journal of Community Psychology, 42, 924-936. doi:10.1002/ jcop.21662

*Flores-González, N. (2000). The structuring of extracurricular opportunities and Latino student retention. Journal of Poverty, 4, 85-108.

*Furlong, M., \& Quirk, M. (2011). The relative effects of chronological age on Hispanic students' school readiness and Grade 2 academic achievement. Contemporary School Psychology, 15, 81-92.

Gándara, P., \& Contreras, F. (2009). The Latino education crisis: The consequences of failed social policies. Cambridge, MA: Harvard University Press.

*Garrett, T., Antrop-González, R., \& Vélez, W. (2010). Examining the success factors of highachieving Puerto Rican male high-school students. Roeper Review, 32, 106-115. doi: $10.1080 / 02783191003587892$

Garza, R. (2009). Latino and White high school students' perceptions of caring behaviors: Are we culturally responsive to our students? Urban Education, 44, 297-321. doi: $10.1177 / 0042085908318714$

*Gibson, M. A., \& Bejínez, L. F. (2002). Dropout prevention: How migrant education supports Mexican youth. Journal of Latinos and Education, 1, 155-175.

*Goza, F., \& Ryabov, I. (2009). Adolescents' educational outcomes: Racial and ethnic variations in peer network importance. Journal of Youth and Adolescence, 38, 1264-1279. doi:10.1007/s10964-009-9418-8

*Griffin, B. W. (2002). Academic disidentification, race, and high school dropouts. The High School Journal, 85(4), 71-81. 
*Guglielmi, R. S. (2008). Native language proficiency, English literacy, academic achievement, and occupational attainment in limited-English-proficient students: A latent growth modeling perspective. Journal of Educational Psychology, 100, 322-342. doi:10.1037/0022-0663.100.2.322

Gutstein, E. (2003). Teaching and learning mathematics for social justice in an urban, Latino school. Journal for Research in Mathematics Education, 34, 37-73.

*Guzmán, M. R., Santiago-Rivera, A. L., \& Haase, R. F. (2005). Understanding academic attitudes and achievement in Mexican-origin youths: Ethnic identity, other-group orientation, and fatalism. Cultural Diversity and Ethnic Minority Psychology, 11, 3-15.

Hall, D. T., \& Damico, J. (2007). Black youth employ African American Vernacular English in creating digital texts. The Journal of Negro Education, 76, 80-88.

*Hannon, B. (2015). Hispanics' SAT scores: The influences of level of parental education, performance-avoidance goals, and knowledge about learning. Hispanic Journal of Behavioral Sciences, 37, 204-222. doi:10.1177/0739986315573249

Hermes, M. (2005). Complicating discontinuity: What about poverty? Curriculum Inquiry, 35, 926.

*Hong, S., \& You, S. (2012). Understanding Latino children's heterogeneous academic growth trajectories: Latent growth mixture modeling approach. The Journal of Educational Research, 105, 235-244. doi:10.1080/00220671.2011.584921

Hughes, C. A. (2003). What teacher education programs can learn from successful Mexican descent students. Bilingual Research Journal, 27, 225-244.

Hussar, W. J., \& Bailey, T. M. (2016). Projections of education statistics to 2023 (NCES 2015073). Washington, DC: National Center for Education Statistics, U.S. Department of 
Education, U.S. Government Printing Office. Retrieved from http://nces.ed.gov/pubs2015/2015073.pdf

*Jabagchourian, J. J., Sorkhabi, N., Quach, W., \& Strage, A. (2014). Parenting styles and practices of Latino parents and Latino fifth graders' academic, cognitive, social, and behavioral outcomes. Hispanic Journal of Behavioral Sciences, 36, 175-194. doi:10.1177/0739986314523289

Jennings, L. B., \& Smith, C. P. (2002). Examining the role of critical inquiry for transformative practices. Teachers College Record, 104, 456-81.

*Jiang, Y. H., Yau, J., Bonner, P., \& Chiang, L. (2011). The role of perceived parental autonomy support in academic achievement of Asian and Latino American adolescents. Electronic Journal of Research in Educational Psychology, 9, 497-522.

*Jimenez-Castellanos, O. (2010). Relationship between educational resources and school achievement: A mixed method intra-district analysis. Urban Review, 42, 351-371. doi: $10.1007 / \mathrm{s} 11256-010-0166-6$

*Johnson, C. C., \& Fargo, J. D. (2014). A study of the impact of transformative professional development on Hispanic student performance on state mandated assessments of science in elementary school. Journal of Science Teacher Education, 25, 845-859. doi:10.1007/s10972-014-9396-X

*Kalogrides, D. (2009). Generational status and academic achievement among Latino high school students: Evaluating the segmented assimilation theory. Sociological Perspectives, 52, 159-183. doi:10.1525/sop.2009.52.2.159

Komarraju, M., \& Cokley, K. O. (2008). Horizontal and vertical dimensions of individualcollectivism: A comparison of African Americans and European Americans. Cultural 
Diversity and Ethnic Minority Psychology, 14(4), 336-343. doi: 10.1037/10999809.14.4.336

Ladson-Billings, G. (2009). The dreamkeepers: Successful teachers of African American children. San Francisco, CA: Jossey-Bass.

*Lagerwey, M. D., Phillips, E., \& Fuller, M. (2003). Voices from the pipeline: High school completion among rural Latinos. Journal of Cultural Diversity, 10, $42-49$.

*Lapayese, Y., Huchting, K., \& Grimalt, O. (2014). Gender and bilingual education: An exploratory study of the academic achievement of Latina and Latino English learners. Journal of Latinos and Education, 13, 152-160. doi:10.1080/1534843 1.2013.821067

*LeCroy, C. W., \& Krysik, J. (2008). Predictors of academic achievement and school attachment among Hispanic adolescents. Children \& Schools, 30, 197-209.

Leonard, J., Napp, C., \& Adeleke, S. (2009, November/December). The complexities of culturally relevant pedagogy: A case study of two secondary mathematics teachers and their ESOL students. The High School Journal.

Lewis, J. L., \& Kim, E. (2008). A desire to learn: African American children's positive attitudes toward learning within school cultures of low expectations. Teachers College Record, $110,1304-1329$.

*Lindholm-Leary, K., \& Borsato, G. (2005). Hispanic high schoolers and mathematics: Followup of students who had participated in two-way bilingual elementary programs. Bilingual Research Journal, 29, 641-652. doi:10.1080/15235882.200 5.10162856

*Lleras, C., \& Rangel, C. (2009). Ability grouping practices in elementary school and African American/Hispanic achievement. American Journal of Education, 115, 279-304. 
*Lopez, C. O., \& Donovan, L. (2009). Involving Latino parents with mathematics through family math nights: A review of the literature. Journal of Latinos and Education, 8, 219230. doi:10.1080/15348430902888666

*Lopez, E. M., Gallimore, R., Garnier, J., \& Reese, L. (2007). Preschool antecedents of mathematics achievement of Latinos: The influence of family resources, early literacy experiences, and preschool attendance. Hispanic Journal of Behavioral Sciences, 29, 456-471. doi:10.1177/0739986307305910

*López, F. (2011). The non-generalizability of classroom dynamics as predictors of achievement for Hispanic students in upper elementary grades. Hispanic Journal of Behavioral Sciences, 33, 350-376. doi:10.1177/0739986311415222

Loza, P. P. (2003). A system at risk: College outreach programs and the educational neglect of underachieving Latino high school students. The Urban Review, 35, 43-57.

*Lozano, A. L., Watt, K. M., \& Huerta, J. H. (2009). A comparison study of 12 th grade Hispanic students' college anticipations, aspirations, and college preparatory measures. American Secondary Education, 38, 92-110.

*Lutz, A. (2004). Dual language proficiency and the educational attainment of Latinos. Migraciones Internacionales, 2(4), 95-122.

Marx, S. (2008). "Not blending in": Latino students in a predominantly White school. Hispanic Journal of Behavioral Sciences, 30, 69-88. doi:10.1177/0739986307311906

*Maurizi, L. K., Ceballo, R., Epstein-Ngo, Q., \& Cortina, K. S. (2013). Does neighborhood belonging matter? Examining school and neighborhood belonging as protective factors for Latino adolescents. American Journal of Orthopsychiatry, 83, 323-334. doi:10.1111/ajop. 12017 
*Mayer, M. (2004). The dropout rates of Mexican students in two California cities. Research for Educational Reform, 9(2), 14-24.

*Maynard, B. R., Kjellstrand, E. K., \& Thompson, A. M. (2014). Effects of check and connect on attendance, behavior, and academics: A randomized effectiveness trial. Research on Social Work Practice, 24, 296-309. doi:10.1177/1049731513497804

Meador, E. (2005). The making of marginality: Schooling for Mexican immigrant girls in the rural southwest. Anthropology \& Education Quarterly, 36, 149-164.

*Mena, J. A. (2011). Latino parent home-based practices that bolster student academic performance. Hispanic Journal of Behavioral Sciences, 33, 490-506. doi: $10.1177 / 0739986311422897$

Moses, R., \& Cobb, C. (2001). Radical equations: Civil rights from Mississippi to the Algebra Project. Boston, MA: Beacon Press.

*Mosqueda, E., \& Maldonado, S. I. (2013). The effects of English language proficiency and curricular pathways: Latina/os' mathematics achievement in secondary schools. Equity \& Excellence in Education, 46, 202-219. doi:10.1080/10665 684.2013.780647

*Muller, C., Riegle-Crumb, C., Schiller, K. S., Wilkinson, L., \& Frank, K. A. (2010). Race and academic achievement in racially diverse high schools: Opportunity and stratification. Teachers College Record, 112, 1038-1063.

National Center for Education Statistics. (2015). State profiles. Retrieved from http:// nces.ed.gov/nationsreportcard/states

Noguera, P. A. (2001). The elusive quest for equity and excellence. Education and Urban Society, 34, 18-41. 
Ocasio, K. M. (2014). Nuestro camino: A review of literature surrounding the Latino teacher pipeline. Journal of Latinos and Education, 13, 244-261. doi:10.1080/1 5348431.2014 .887467

Ortiz, C. J., Valerio, M. A., \& Lopez, K. (2012). Trends in Hispanic academic achievement: Where do we go from here? Journal of Hispanic Higher Education, 11, 136-148. doi: $10.1177 / 1538192712437935$

*Oyserman, D., Brickman, D., Bybee, D., \& Celious, A. (2006). Fitting in matters: Markers of in-group belonging and academic outcomes. Psychological Science, 17, 854-861.

*Padilla, A. M., \& Gonzalez, R. (2001). Academic performance of immigrant and U.S.-born Mexican heritage students: Effects of schooling in Mexico and bilingual/ English language instruction. American Educational Research Journal, 38, 727-742.

Padilla, R. V. (2007). Camino a la universidad: The road to college. Indianapolis, IN: Lumina Foundation. Retrieved from https://www.luminafoundation.org/files/ publications/The_Road_To_College_for_Latinos.pdf

*Park, H., Lin, C., Liu, C., \& Tabb, K. M. (2015). The relationships between after-school programs, academic outcomes, and behavioral developmental outcomes of Latino children from immigrant families: Findings from the 2005 National Household Education Surveys Program. Children and Youth Services Review, 53, 77-83. doi:10.1016/j.childyouth.2015.03.019

*Park, H. S., \& Yau, J. (2014). The relationship between library use and academic achievement of English and Spanish-speaking Hispanic American students. Educational Research Quarterly, 37(4), 3-18. 
Patten, E. (2016). The nation's Latino population is defined by its youth. Pew Research Center. Retrieved from http://www.pewhispanic.org/2016/04/20/the-nations-latino-population-isdefined-by-its-youth/

*Pong, S., \& Landale, N. S. (2012). Academic achievement of legal immigrants' children: The roles of parents' pre- and post-migration characteristics in origin-group differences. Child Development, 83, 1543-1559. doi:10.1111/j.1467-8624.2012.01790.

Pounder, D. G., \& Johnson, B. L. (2009). Review of literature submissions to EAQ: General call and invitation. Educational Administration Quarterly, 45, 3.

doi:10.1177/0013161X08330750

*Prelow, H. M., \& Loukas, A. (2003). The role of resource, protective, and risk factors on academic achievement-related outcomes of economically disadvantaged Latino youth. Journal of Community Psychology, 31, 513-529. doi:10.1002/ jcop.10064

*Quirk, M., Nylund-Gibson, K., \& Furlong, M. (2013). Exploring patterns of Latino/a children's school readiness at kindergarten entry and their relations with Grade 2 achievement. Early Childhood Research Quarterly, 28, 437-449. doi:10.1016/j. ecresq.2012.11.002

Quiroz, P. A. (2001). The silencing of Latino student "voice": Puerto Rican and Mexican narratives in eighth grade and high school. Anthropology \& Education Quarterly, 32, 326-349.

*Reyes, O. (1993). Follow-up study on low- and high-risk Hispanic high school students. Journal of Community Psychology, 21, 218-226.

*Reyes, O., \& Jason, L. A. (1991). An evaluation of a high school dropout prevention program. Journal of Community Psychology, 19, 221-230. 
*Riconscente, M. M. (2014). Effects of perceived teacher practices on Latino high school students' interest, self-efficacy, and achievement in mathematics. The Journal of Experimental Education, 82, 51-73. doi:10.1080/00220973.2013.813358

*Riegle-Crumb, C. (2010). More girls go to college: Exploring the social and academic factors behind the female postsecondary advantage among Hispanic and White students. Research in Higher Education, 51, 573-593. doi:10.1007/ s11162-010-9169-0

*Riegle-Crumb, C., \& Callahan, R. M. (2009). Exploring the academic benefits of friendship ties for Latino boys and girls. Social Science Quarterly, 90, 611-631.

*Rios-Aguilar, C. (2010). Measuring funds of knowledge: Contributions to Latina/o students' academic and nonacademic outcomes. Teachers College Record, 112, 2209-2257.

*Rivas-Drake, D. (2011). Public ethnic regard and academic adjustment among Latino adolescents. Journal of Research on Adolescence, 21, 537-544. doi:10.1111/ j.15327795.2010.00700.x

*Rodríguez, B. A. (2014). The threat of living up to expectations: Analyzing the performance of Hispanic students on standardized exams. Journal of Hispanic Higher Education, 13, 191-205. doi:10.1177/1538192714531292

*Roosa, M. W., O’Donnell, M., Cham, H., Gonzales, N. A., Zeiders, K. H., Tein, J., .. . UmañaTaylor, A. (2012). A prospective study of Mexican American adolescents' academic success: Considering family and individual factors. Journal of Youth and Adolescence, 41, 307-319. doi:10.1007/s10964-011-9707-x

*Ryabov, I., \& Van Hook, J. (2007). School segregation and academic achievement among Hispanic children. Social Science Research, 36, 767-788. doi:10.1016/j. ssresearch.2006.04.002 
Ryan, C. L., \& Bauman, K. (2016). Educational attainment in the United States: 2015 (P20-578): Economics \& Statistics Administration, U.S. Department of Commerce, U.S. Census Bureau. Retrieved from http://www.census.gov/content/ dam/Census/library/publications/2016/demo/p20-578.pdf

*Sánchez, B., Colón, Y., \& Esparza, P. (2005). The role of sense of school belonging and gender in the academic adjustment of Latino adolescents. Journal of Youth and Adolescence, 34, 619-628.

*Santiago, C. D., Gudiño, O. G., Baweja, S., \& Nadeem, E. (2014). Academic achievement among immigrant and U.S.-born Latino adolescents: Associations with cultural, family, and acculturation factors. Journal of Community Psychology, 42, 735-747. doi:10.1002/jcop.21649

Sheets, R. S. (1995). From remedial to gifted: Effects of culturally centered pedagogy. Theory into Practice, 34, 186-193.

Sleeter, C. E. (2010, November). Confronting the marginalization of culturally responsive pedagogy. Paper presented at the Culturally Responsive Pedagogies Symposium, Hamilton, New Zealand.

Snyder, T. D., de Brey, C., \& Dillow, S. A. (2016). Digest of education statistics 2014 (NCES 2016-006). Washington, DC: National Center for Education Statistics, Institute of Education Sciences, U.S. Department of Education. Retrieved from http://nces.ed.gov/pubs2016/2016006.pdf

Solórzano, D. G., \& Ornelas, A. (2004). A critical race analysis of Latina/o and African American advanced placement enrollment in public high schools. The High School Journal, 87(3), 15-26. 
*Song, H., \& Elliott, W. (2012). The effects of parents' college savings on college expectations and Hispanic youth's four-year college attendance. Children and Youth Services Review, 34, 1845-1852. doi:10.1016/j.childyouth.2012.05.022

Steele, C. M. (2010). Whistling Vivaldi: How stereotypes affect us and what we can do. New York, NY: W.W. Norton.

Steele, C. M., \& Aronson, J. (1995). Stereotype threat and the intellectual test performance of African Americans. Journal of Personality and Social Psychology, 69, 797-811.

Stepler, R., \& Brown, A. (2016). Statistical portrait of Hispanics in the United States. Pew Research Center. Retrieved from http://www.pewhispanic.org/2016/04/19/ statisticalportrait-of-hispanics-in-the-united-states-key-charts/

*Supple, A. J., Chazatian, S. R., Frabutt, J. M., Plunkett, S. W., \& Sands, T. (2006). Contextual influences on Latino adolescent ethnic identity and academic outcomes. Child Development, 77, 1427-1433.

*Taggart, A. (2017). The role of cultural discontinuity in the academic outcomes of Latina/o high school students. Education and Urban Society, 49, 731-761. doi:

$10.1177 / 0013124516658522$

*Taggart, A., \& Crisp, G. (2011). The role of discriminatory experiences on Hispanic students' college choice decisions. Hispanic Journal of Behavioral Sciences, 33, 22-38. doi: $10.1177 / 0739986310386750$

Tan, G. (2001). "I want my teachers to like me": Multiculturalism and school dropout rates among Mexican Americans. Equity \& Excellence in Education, 34(2), 35-42. doi:10.1080/1066568010340206 
Tan, G. (2002). The need for multiculturalism in the classroom as perceived by Mexican American schoolchildren. Multicultural Education, 9(3), 21-24.

*Tillman, K. H., Cuo, G., \& Harris, K. M. (2006). Grade retention among immigrant children. Social Science Research, 35, 129-156. doi:10.1016/j.ssre-search.2004.07.001

*Turner, E. E., \& Celedón-Pattichis, S. (2011). Mathematical problem solving among Latina/o kindergartners: An analysis of opportunities to learn. Journal of Latinos and Education, 10, 146-169. doi:10.1080/15348431.2011.556524

Valencia, R. R. (2000). Inequalities and the schooling of minority students in Texas: Historical and contemporary conditions. Hispanic Journal of Behavioral Sciences, 22, 445-459. doi: $10.1177 / 0739986300224005$

*Valle, M. S., Diaz, Z., Waxman, H. C., \& Padrón, Y. N. (2013). Classroom instruction and the mathematics achievement of non-English learners and English learners. The Journal of Educational Research, 106, 173-182. doi:10.1080/0022067 1.2012.687789

Van Horn, L. (2000). Self-determination and cultural empowerment: Reader histories reveal learning and adaptation strategies. The Urban Review, 32, 177-195.

Walton, G. M., \& Spencer, S. J. (2009). Latent ability: Grades and test scores systematically underestimate the intellectual ability of negatively stereotyped students. Psychological Science, 20, 1132-1139.

*Weiher, G. R., Hughes, C., Kaplan, N., \& Howard, J. Y. (2006). Hispanic college attendance and the state of Texas GEAR UP program. Review of Policy Research, 23, 1035-1051.

Wortham, S., \& Contreras, M. (2002). Struggling toward culturally relevant pedagogy in the Latino diaspora. Journal of Latinos and Education, 1, 133-144. 
*Yoshikawa, H., Gassman-Pines, A., Morris, P. A., Gennetian, L. A., \& Godfrey, E. B. (2010). Racial/ethnic differences in effects of welfare policies on early school readiness and later achievement. Applied Developmental Science, 14, 137-153.

doi:10.1080/10888691.2010.493068

*Zarate, M. E., Bhimji, F., \& Reese, L. (2005). Ethnic identity and academic achievement among Latino/a adolescents. Journal of Latinos and Education, 4, 95-114.

*Zarate, M. E., \& Gallimore, R. (2005). Gender differences in factors leading to college enrollment: A longitudinal analysis of Latina and Latino students. Harvard Educational Review, 75, 383-408.

*Zarate, M. E., \& Pineda, C. G. (2014). Effects of elementary school home language, immigrant generation, language classification, and school's English learner concentration on Latinos' high school completion. Teachers College Record, 116, 1-37. 